\title{
Proximate analysis: Relative feed values of various forage plants for ruminants investigated in a semi-arid region of Punjab, Pakistan
}

\author{
Kafeel Ahmed ${ }^{1}$, Muneeba Shaheen ${ }^{1}$, Farhad Mirzaei ${ }^{2}$, Zafar Iqbal Khan ${ }^{1}$, Sumaira Gondal ${ }^{1}$, \\ Asia Fardous $^{1}$, Abrar Hussain ${ }^{3}$, Fahim Arshad ${ }^{4}$, Tahir Mehmood ${ }^{5}$ \\ ${ }^{1}$ Department of Biological Sciences, University of Sargodha, Sargodha, Pakistan \\ ${ }^{2}$ Livestock Production Management Department, Animal Science Research Institute of Iran, Karaj, Iran; \\ *Corresponding Author: farmir2005@gmail.com \\ ${ }^{3}$ Science and Technology Division, University of Education, Township Campus, Lahore, Pakistan \\ ${ }^{4}$ Department of Botany, University of Education, Okara Campus, Okara, Pakistan \\ ${ }^{5}$ Department of Statistics, University of Sargodha, Sargodha, Pakistan
}

Received 8 February 2013; revised 9 March 2013; accepted 10 April 2013

Copyright (C) 2013 Kafeel Ahmed et al. This is an open access article distributed under the Creative Commons Attribution License, which permits unrestricted use, distribution, and reproduction in any medium, provided the original work is properly cited.

\section{ABSTRACT}

The experimental site "Sial Morr Sugar mill, District Sargodha" Punjab, Pakistan was selected to carry out present investigation. The forage samples of Eragrostis pilosa, Dactyloctenium aegyptium, Parthenium hysterophorus and Calotropis procera were collected from the three sites held in this area. The forage samples were cleaned with distilled water to rinse dust particles and other impurities. These forage samples were air dried, oven dried and ground for the assessment of proximate analysis. Proximate analysis procedures including the percentage of moisture content, crude protein, ash contents and crude fiber in the sample were determined by the Association of Official Analytical Chemists methods. The CP contents among different plant species ranged from $8.1 \%$ to $26.2 \%$ at all sites. The lowest CP value was found in Eragrostis pilosa at site III while the highest CP contents in Dactyloctenium aegyptium at site II. The CP content showed significant $(p<0.05)$ result among all species at all sites. There was consistence pattern of increase and decrease found during all plant species at all sites. Generally, CP concentration averaged high at site II. Our CP contents are above the critical value. Considering the overall percentage of moisture composition, it was highest at site II. However, the moisture was found more in Calotropis procera at site II. The Dactyloctenium aegyptium had the least moisture content of $3.9 \%$ while the highest water content of $7 \%$. Ash contents varied from $7.2 \%$ to $17.9 \%$ among various plant species at all sampling sites. The lowest ash contents were recorded in Dactyloctenium aegyptium at site III. At site II, ash contents were highest in Eragrostis pilosa. The differences between ash contents of various plant species were significant $(p<0.05)$ at all sampling site. Generally, the ash contents were higher at site II. Crude fiber contents differed significantly $(p<$ 0.05 ) between various plant species at all sampling sites stages. Parthenium hysterophorus had greater crude fiber contents at site II while the lowest value of CF found in Dactyloctenium aegyptium at site I. The differences were significant between all plant species other than the Specie I at all sites. The values ranged from $1.2 \%$ to $4.1 \%$. It was highest in Parthenium hysterophorus (4.1\%) at site I and least in Dactyloctenium aegyptium (1.2\%) at site III. Maximum ether extract value was achieved at site $I$.

Keywords: Eragrostis pilosa; Dactyloctenium aegyptium; Parthenium hysterophorus; Calotropis procera; Nutritional Values; Proximate Contents

\section{INTRODUCTION}

In Pakistan, almost 1000 species of plants have been indicated with therapeutic and medicinal value, used to save communities from diseases [1,2]. Naturally all liv- 
ing organisms have been gifted by plant commodities that have medicinal values. The vitality of several plants has been demonstrated by earlier researchers while a great number of them are still now unexplored. So it is essential to explore their nutritive contents [2]. Protein, carbohydrates, and fats are the necessary elements of life. The characteristics and amount of proteins present in the seeds are major element and important for the selection of plants for nutrition, systematic categorization and plant development programs [3]. The researchers were aware with the medicinal values of plants since ancient times. The improvement in medicines that were obtained from plant was mostly due to traditional information about health care at several times. From this study it is revealed that there is an interaction present among pure nutrients and crude extracts consumed in traditional medicine [4].

To provide scientific basis for the use of some of these plants in the treatment of many diseases of microbial origin, many studies have been screened for antimicrobial activities and have been found promising. Extraction of different biological molecules derived from various medicinal plants allowed the affirmation of their physiological functions [5]. The effective plant components which supplied active therapeutic potential were present in all plant organs, while their quantity will be greater in one structure that more preferred. These organs were roots, flower, bark of the stem, fruit, leaves, and seeds [6]. The biologically active compounds containing natural origins were much more important for the researchers at the time of studying infectious disorders. Their interest is increasing by investigation of plants ability to resist various diseases as they have antibacterial function for survival [7]. With the varied atmospheric conditions and other edaphic factors, Pakistan has been blessed with a number of forage plants that presented diversity and important medicinal plant heritage. This type of diversity of plants was seen in few countries of the world. Due to this our country plants have played very significant role in herbal medicine [8]. Considering the importance of these plants, species for grazing livestock were subjected to proximate analysis. The major goal of this study was to determine the chemical compositions proximate in forage species. The present research was conducted to describe the nutritional potential of some forage plants of this rangeland at different sites. This research will help the stockmen and range managers to improve the forage quality as well as quantity for the growth enhancement of grazing livestock and their yield.

\section{MATERIALS AND METHODS}

\subsection{Study Site}

The study site "Sial Morr Sugar mill, in District Sargodha” Punjab, Pakistan was selected to carry out pre- sent investigation. The average rainfall is $180-200 \mathrm{~mm}$ mostly in month of July and August. Sargodha district is located at $32^{\circ} 08^{\prime} 00$ north latitude and $73^{\circ} 7^{\prime} 00$ east longitude.

\subsection{Sample Collection}

The forage samples of Eragrostis pilosa, Dactyloctenium aegyptium, Parthenium hysterophorus and Calotropis procera were collected from the three sites from Sial Morr Sugar mill at a distance of $12 \mathrm{~km}$, District Sargodha. The samples of forage were washed with distilled water to remove impurities and dust particles and then placed in an oven $\left(65^{\circ} \mathrm{C}\right)$ to dry, after that they were grounded and kept in air-tight plastic containers at room temperature $\left(30^{\circ} \mathrm{C}\right)$ for further analysis.

\subsection{Proximate Analysis}

Procedure including the percentage of moisture content, crude protein, ash contents and crude fiber in the sample were determined by The Association of Official Analytical Chemists methods [9].

\subsection{Crude Protein}

The contents of crude proteins in samples were estimated by using macro-Kjeldahl method, in which digestion of samples was done with considerable amount of acid. After adding alkali, distilled the digested material. The released ammonia was collected in 4\% boric acid. Boric acid along with ammonia was titrated against 0.1 $\mathrm{NH}_{4} \mathrm{Cl}$ and by multiplying with 6.25 percentages of nitrogen was converted into protein.

\subsection{Moisture Content}

Aluminum dish were dried in oven for $2 \mathrm{~h}$ at $105^{\circ} \mathrm{C}$. For cooling, crucible was positioned in the desiccators to allow cooling. Weighed the aluminum dish and placed 2 $\mathrm{g}$ on it. The samples were oven dried at $100^{\circ} \mathrm{C}$ for 3 to 4 $\mathrm{hr}$ and then weighed to determine the percentage moisture content.

\subsection{Ash}

Ash analysis was similar to that of moisture content. 2 g sample was placed in crucible, weighed and put in muffle oven at $550^{\circ} \mathrm{C}$ for $8 \mathrm{hr}$.

\subsection{Crude Fiber}

2 g sample was put into $250 \mathrm{ml}$ of conical flask and added $1.25 \%$ Sulfuric acid solution and then heated for about $30 \mathrm{~min}$, filtered then washed until traces of acid could not be detected using $\mathrm{pH}$ paper. The acid extracted was transferred into $250 \mathrm{ml}$ flask and added 1.25\% 
$\mathrm{NaOH}$ subsequently. Heated the samples for $30 \mathrm{~min}$ and filtered and washed. The material was transferred into crucible and oven dried at $120^{\circ} \mathrm{C}$ for $12 \mathrm{~h}$. After it, crucibles were placed in muffle oven for $12 \mathrm{~h}$ at $550^{\circ} \mathrm{C}$ and recorded the crucible weight.

\subsection{Ether Extract}

A dried sample (2 g) was extracted with petroleum ether $\left(4^{\circ} \mathrm{C}-60^{\circ} \mathrm{C}\right)$ in soxhlet apparatus to remove the ether soluble component present in it. The extracted material was dried to a constant weight in an oven at $70^{\circ} \mathrm{C}$.

\subsection{Statistical Analysis}

Statistical analysis of data was done by using SPSS software, and one-way analysis of variance was used. At 0.05 probability level, significance between means was tested as suggested by Steel and Torrie [10].

\section{RESULTS AND DISCUSSION}

\subsection{Crude Protein}

The CP contents among different plant species ranged from $8.1 \%$ to $26.2 \%$ at all sites (Figure 1). The lowest $\mathrm{CP}$ value was found in Eragrostis pilosa at pasture III while the highest CP contents in Dactyloctenium aegyptium at pasture II. The CP content showed significant (P $<0.05$ ) result among all species at all sites (Table 1). There was consistence pattern of increase and decrease found during all plant species at all sites. Generally, CP concentration averaged high at site II. Our CP contents are above the critical value of $7.0 \%$ as reported by Minson [11]. Kiatoko et al. [12] also reported normal higher mean forage protein values of $9.4 \%$ and $8.45 \%$ for the seasons. This result agrees with Ganskopp \& Bohner [13] who reported high CP contents in various forage species. Ruminants need protein for maintaining growth and re-

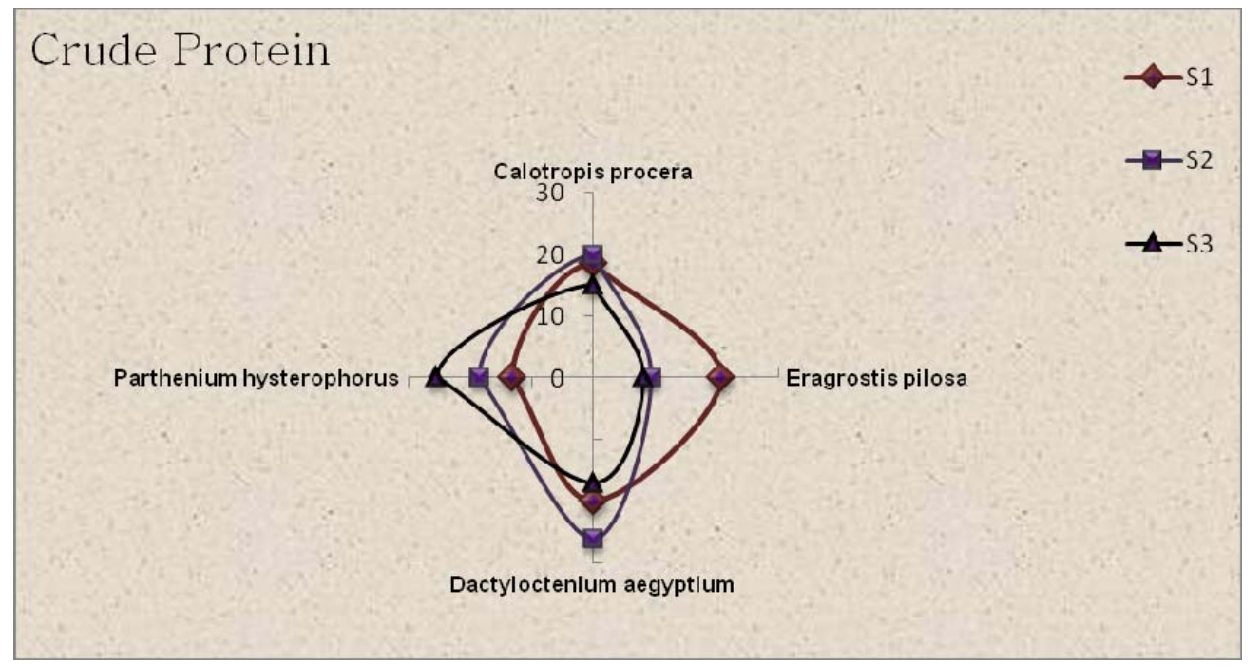

Figure 1. Fluctuations in crude protein in various plant species at different sampling sites.

Table 1. Statistical analysis of proximate composition of various forage plant species.

\begin{tabular}{|c|c|c|c|c|c|c|c|}
\hline \multirow{2}{*}{\multicolumn{2}{|c|}{ Source of Variation (S.O.V) }} & \multirow{2}{*}{$\begin{array}{c}\text { Degree of } \\
\text { Freedom (df) }\end{array}$} & \multicolumn{5}{|c|}{ Mean Squares } \\
\hline & & & Crude Protein & ASH & MOIST. & Crude FIBER & E.E. (OIL) \\
\hline \multirow{4}{*}{$\begin{array}{l}\text { Plant } \\
\text { Species }\end{array}$} & C. procera & \multirow{4}{*}{2} & $24.176^{*}$ & $8.978^{*}$ & $3.001^{*}$ & $44.782^{*}$ & $0.466^{\text {ns }}$ \\
\hline & E. pilosa & & $141.123^{*}$ & $12.923^{*}$ & $1.470^{*}$ & $635.597^{*}$ & $8.356^{*}$ \\
\hline & D. aegyptium & & $200.626^{*}$ & $86.043^{*}$ & $0.703^{*}$ & $29.323^{*}$ & $2.431^{*}$ \\
\hline & P. hysterophorus & & $91.251^{*}$ & $19.511^{*}$ & $8.173^{*}$ & $226.053^{*}$ & $4.731^{*}$ \\
\hline \multirow{4}{*}{ Error } & C. procera & \multirow{4}{*}{9} & 0.080 & 0.216 & 0.150 & 0.142 & 0.131 \\
\hline & E. pilosa & & 0.180 & 0.201 & 0.248 & 0.249 & 0.157 \\
\hline & D. aegyptium & & 0.202 & 0.163 & 0.129 & 0.157 & 0.108 \\
\hline & P. hysterophorus & & 0.156 & 0.112 & 0.118 & 0.106 & 0.134 \\
\hline
\end{tabular}

\footnotetext{
${ }^{*}=$ significant, ns = non significant.
} 
production. The deficiency of proteins leads to reduced appetite, low feed intake and poor food efficiency that in turn results in poor growth and development of livestock [14]. Current study results agree with Holechek et al. [15], who also reported high CP contents in different plant species. For healthy productivity a continuous supply of CP is required [15]. The livestock is healthier in season when forage is rich in protein contents. The health of animals might decline with decreased protein availability in the range plants. Plants need more nitrogenous food for vegetative growth and therefore they efficiently store protein in early stages of growth, which is later on consumed during flowering and fruiting followed by dormant phase whereby their nutritional status reduces. During this period, dry spell from May to October is characteristic for the area [16]. This is the time when besides reduction in over all availability of forage [17], plants also become poor in quality including crude protein contents. Thus, livestock are compelled to utilize protein deficient feed that causes poor growth. The present study showed that all plant species generally contained adequate CP content and can fulfill the protein requirement of ruminants.

\subsection{Moisture}

Considering the overall percentage of moisture composition, it was highest at pasture II (Figure 2). However, the moisture was found more in Calotropis procera at pasture II. The Dactyloctenium aegyptium had the least moisture content of 3.9\% while the highest water content of $7 \%$. There was significant difference $(\mathrm{P}<0.05)$ among the replicates. The observation during present study was much lower than the values obtained by Oduro et al. [18]. The variation in the nutritional values will differ for a wide range of reasons, such as cultivated regions, growing conditions, nature of soil, seasonal changes, genetically different cultivars and storage conditions or due to the period of analysis [19].

\subsection{Ash Contents}

Ash contents varied from $7.2 \%$ to $17.9 \%$ among various plant species at all sampling sites. The lowest ash contents were recorded in Dactyloctenium aegyptium at pasture III. At pasture II, ash contents were highest in Eragrostis pilosa (Figure 3). The differences between ash contents of various plant species was significant $(\mathrm{P}<$ 0.05) at all sampling pasture Land (Table 1). Generally, the ash contents were higher at pasture II. Ash contents play important role in promoting balanced growth of animals. Similar to this study finding, Kilcher [20] also reported that ash contents of forage progressively decline with advancing maturity. However, Liu [21] observed high ash contents with increasing degree of maturity of plants. In the present study we also recorded higher ash contents in all plant species. This increase or decrease of ash contents at all pasture lands by different plants may be due to variation in soil and other habitat features that need to be explored.

\subsection{Crude Fiber (CF)}

Crude fiber contents differed significantly $(\mathrm{P}<0.05)$ between various plant species at all sampling sites (Table 1). Parthenium hysterophorus had greater crude fibre contents at pasture II while the lowest value of CF found in Dactyloctenium aegyptium at pasture I (Figure 4). The values observed during present findings were similar with the value observed by Holechek et al. [15]. Among all species highest CF contents were found at pasture II. Mature plants usually contained high CF than young plants. Seasonal variation affects the crude fiber contents. Crude fibre is less nutritional than cell contents due to its slow digestibility. The range of crude fibre in the present study was greater when compared to other forage species [22]. As the plants became older, the crude fiber tended to increase for all plants, but for some plants more than others. The crude fiber content found during present

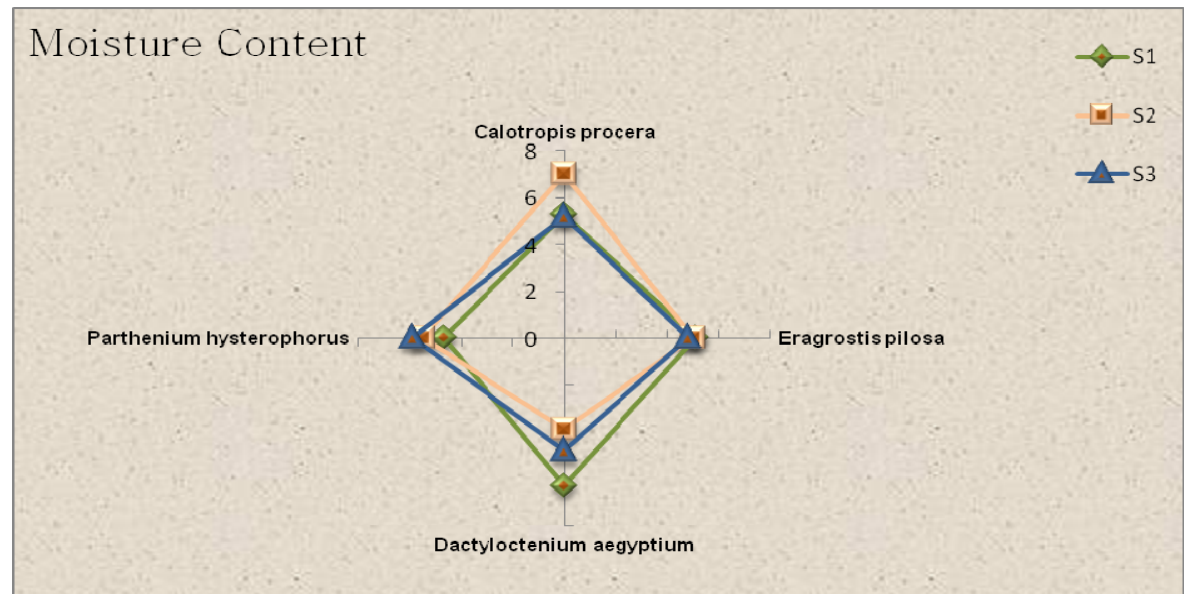

Figure 2. Fluctuations in moisture content in various plant species at different sampling sites. 


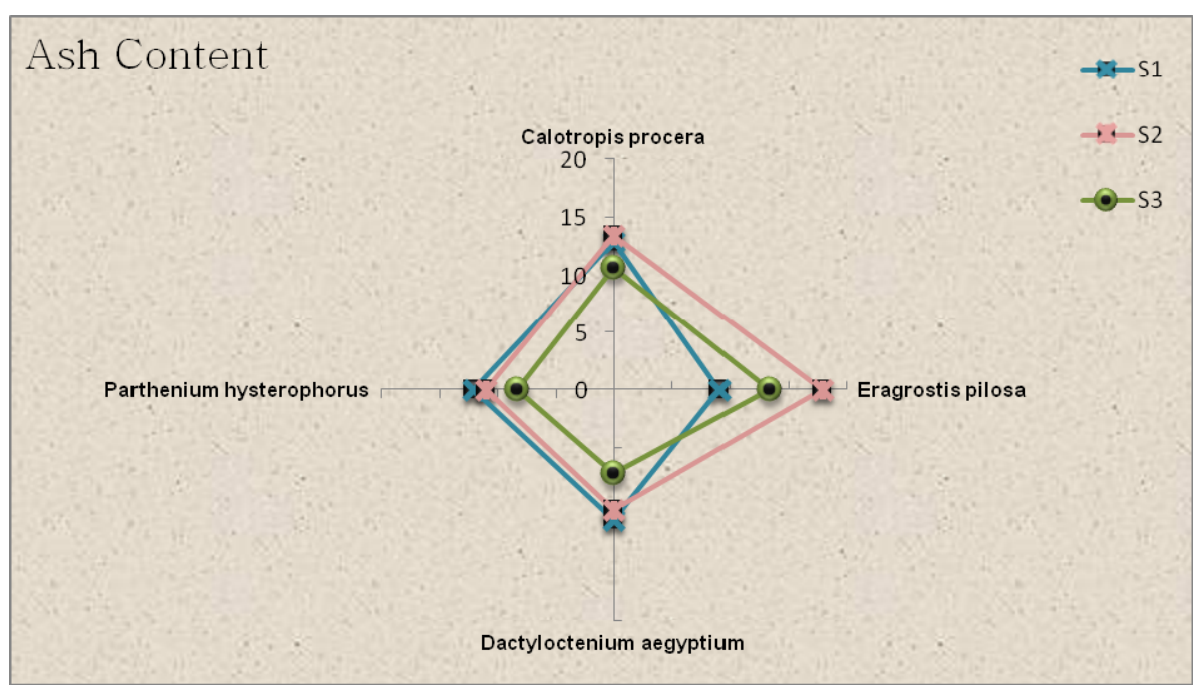

Figure 3. Fluctuations in ash content in various plant species at different sampling sites.

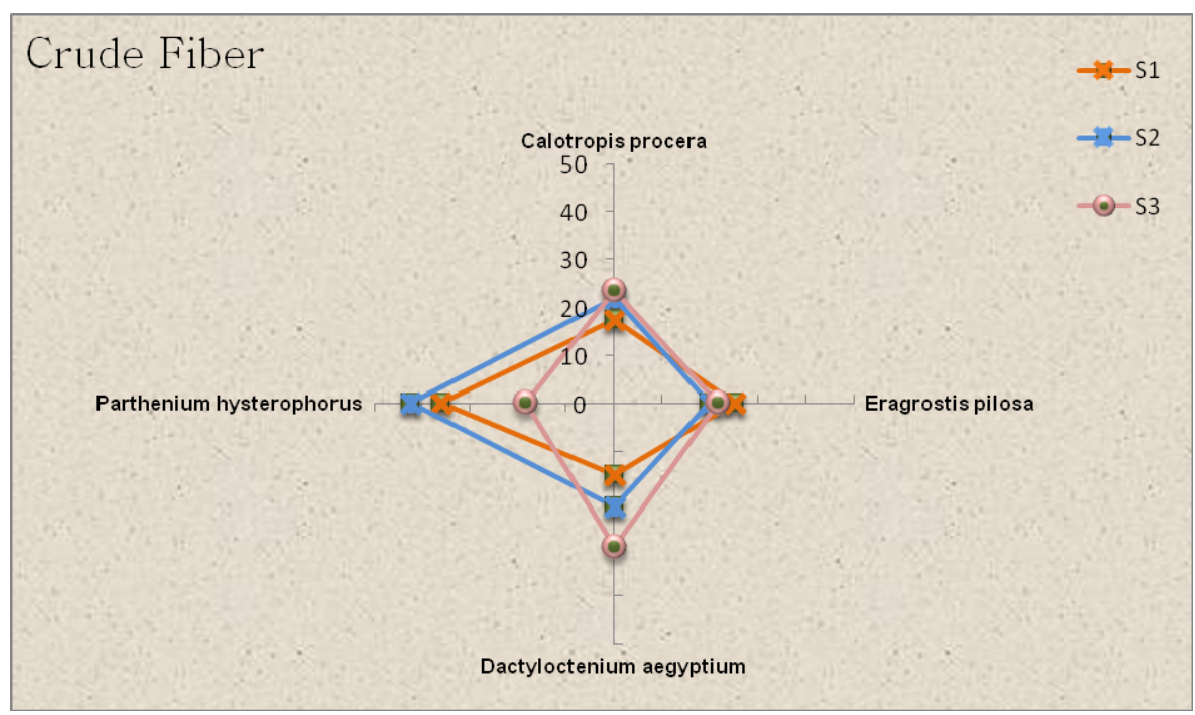

Figure 4. Fluctuations in crude fiber in various plant species at different sampling sites.

findings was ranged from $15 \%$ to $42.4 \%$ which is in range from the recommended value of $31.6 \%$. Therefore adequate amount of crude fiber was present for the proper growth of grazing livestock in this studied land.

\subsection{Ether Extract (EE)}

The differences were significant between all plant species other than the Specie I at all pasture lands (Table 1). The values ranged from $1.2 \%$ to $4.1 \%$. It was highest in Parthenium hysterophorus (4.1\%) at pasture I and least in Dactyloctenium aegyptium (1.2\%) at pasture III (Figure 5). Maximum ether extract value was achieved at site I. The values of EE were found during present study was similar in range of $2.4 \%$. Ether extract is the lipid component and the energy derived from it is utilized by the animal for body maintenance and production.
The higher value of ether extracts in some of the tested samples is an indication of higher energy level for the animal $[23,24]$ and this is a major form of energy storage in plants which is being utilized by the animals for body maintenance and production. All the plant parts have nutritional qualities which when used in the right proportions could be of tremendous benefit to the body. Further studies will concentrate more on the use of the extracts of these plants in laboratory animals in order to determine their metabolic effects.

\section{CONCLUSION}

The samples of Eragrostis pilosa, Dactyloctenium aegyptium, Parthenium hysterophorus and Calotropis procera were obtained from the three sites apprehended in the experimental site "Sial Morr Sugar mill, District Sar- 


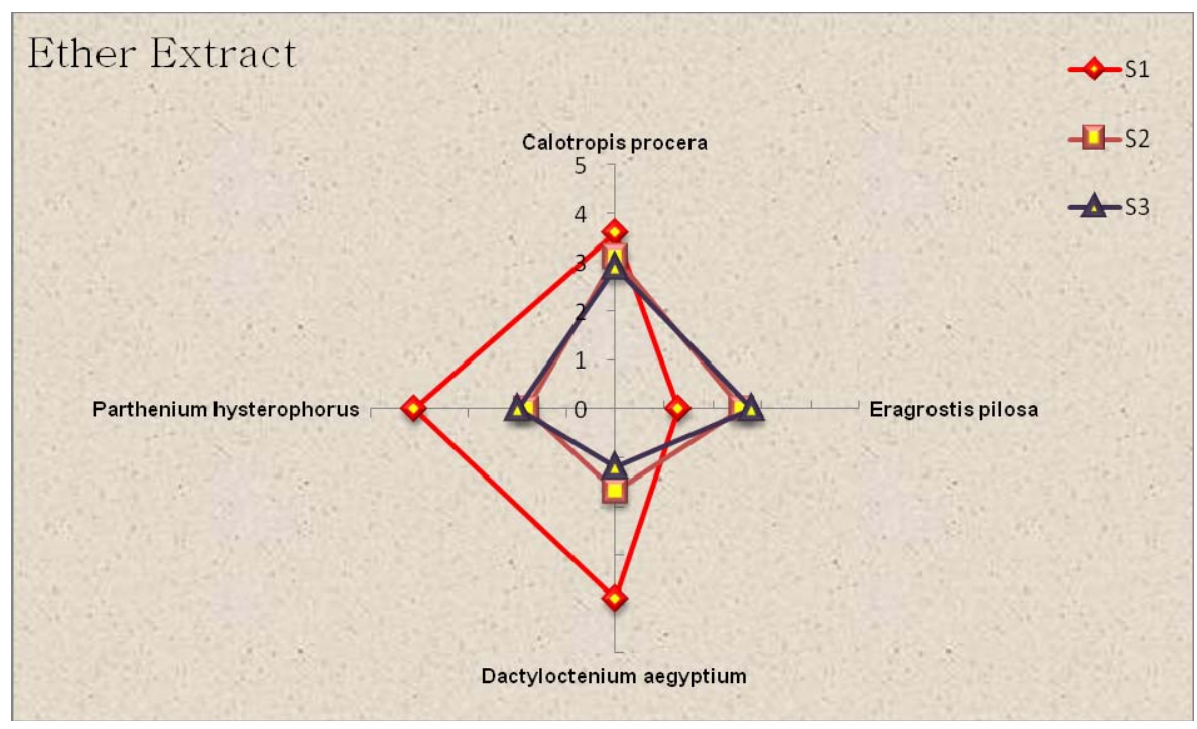

Figure 5. Fluctuations in ether extract in various plant species at different sampling sites.

godha” Punjab, Pakistan. The foremost objective of this study was to identify the chemical compositions, proximate in forage species. The current research was conducted to illustrate the dietary potential of some forage plants of this rangeland at diverse sites. It is concluded that there was a steady pattern of augment and dwindle of nutrients found in different forage species at all sampling sites investigated. All the plant parts had dietary qualities when used in the precise magnitude which could be of remarkable assistance to the body of animal.

\section{REFERENCES}

[1] Latif, A.H., Ahmad, S., Begum, S.K. and Adnan, S.M. (2004) Medicinal and other economic plants as substitute to forest logging in Miandam and Sulatanr Valley-Swat. Proceeding of International Workshop on Conservation and Sustainable Use of Medicinal and Aromatic Plants in Pakistan.

[2] Mushtaq, A.Q., Rahmatullah, A., Muhammad, A.K. and Muhammad, Z. (2009) Traditional herbal remedies used for the treatment of diabetes from district Attock (Pakistan). Pakistan Journal of Botany, 41, 2777-2782.

[3] Nisar, M., Tariq, S.A. and Ullah, I. (2009) Nutritional levels of Indigofera gerdiana Wall and Crataegus songrica K. Koch. Pakistan Journal of Botany, 41, 13591361.

[4] Osho, I.B., Adebayo, I.A., Oyewo, M.O. and Osho, G.T. (2007) Comparative antimicrobial activities of methanolic crude extract of three medicinal plants used in ethnoveterinary practice against some pathogenic microorganisms. Proceedings of the 3rd SAAT Annual Conference, Akure, 16-19 April 2007, 128-133.

[5] Holetz, F., Pessini, G., Sanches, N., Cortez, D., Nakamura, C. and Filho D. (2002) Screening of some plants used in the Brazilian folk medicine for the treatment of infectious diseases. Memórias do Instituto Oswaldo Cruz, 97, 1027-

\section{1. doi:10.1590/S0074-02762002000700017}

[6] Akinleye, O.B., Adu, O.E. and Ayeni, I.A. (1996) Studies of some biological and chemical characteristics of Mexican sunflower (Tithonia diversifolia). Consultation Research Journal, 1, 35-38.

[7] Dhir, M.L., Crayg, G. and Berman, F.W. (2002) Screening of Indian plants for biological activity. Indian Journal of Experimental Biology, 6, 237-247.

[8] Rizwi, M.A. (1998) Medicinal flowers of Pakistan, part III. Horticulture Society of Pakistan, Karachi, 48-52.

[9] AOAC (1990) Official methods of analysis. 15th Edition. Association of Official Analytical Chemists, Washington DC.

[10] Steel, R.G.D. and Torrie, J.H. (1986) Principles and procedures of Statistics. 2nd Edition, McGraw Hill Book Co. Inc., New York, 336-354.

[11] Minson, D.J. (1971) The digestibility and voluntary intake of six varieties of Panicum. Australian Journal of Experimental Agriculture and Animal Husbandry, 11, 1824. doi:10.1071/EA9710018

[12] Kiatoko, M., McDowell, L.R., Bertrand, J.E., Chapman, H.C., Pate, F.M., Martin, F.G. and Conrad, J.H. (1982) Evaluating the nutritional status of beef cattle herds from four soil order regions of Florida: I Macroelements, protein, carotene, vitamins A and E, haemoglobin and haematocrit. Journal of Animal Science, 55, 28-47.

[13] Ganskopp, D. and Bohnert, D. (2001) Nutritional dynamics of 7 northern great basin grasses. Journal of Range Management, 54, 640-647. doi:10.2307/4003664

[14] Anonymous (1985) Nutrient requirements of domestic animals, No. 5, Nutrient requirements of sheep. National Academy of Science, National Research Council, Washington DC.

[15] Holechek, J.L., Pieper, R.D. and Herba, C.H. (1998) Range management. Principles and practices. 3rd Edition, Prentice Hall, Upper Saddle River, 07458.

[16] Durrani, M.J. and Hussain, F. (2005) Ethnoecological 
profile of plants of Harboi rangeland, Balochistan. International Journal of Biology and Biotechnology, 2, 15-22.

[17] Hussain, F. and Durrani, M.J. (2007) Forage productivity of arid temperate Harboi rangeland, Kalat, Pakistan. Pakistan Journal of Botany, 39, 1455-1470.

[18] Oduro, W., Ellis, O. and Owusu, D. (2008) Nutritional potential of two leafy vegetables: Moringa oleifera and Ipomoea batatas leaves. Scientific Research and Essays, 3, 57-60.

[19] Imeh, U. and Khokhar, S. (2002) Distribution of conjugated and free phenols in fruits: Antioxidant activity and cultivar variations. Journal of Agricultural and Food Chemistry, 50, 6301-6306. doi:10.1021/jf020342j

[20] Kilcher, M.R. (1981) Plant development, stage of maturity and nutrient composition. Journal of Range Management, 34, 363-364. doi:10.2307/3897904

[21] Liu, Y.Z. (1993) Study on the dynamic features of nutri- tive substances in Inner Mongolia Steppe. Grassland of China, 4, 16-20.

[22] Ashraf, Y., Gillani, A.H. and Nagra, S.A. (1995) Effect of harvesting interval and varieties on the chemical composition of indigenous fodder. I: Proximate composition. Journal of Agricultural Research, 33, 31-43.

[23] Babayemi, O.J. and Bamikole, M.A. (2006) Effects of Tephrosia candida DC leaf and its mixtures with Guinea grass on in vitro fermentation changes as feed for ruminants in Nigeria. Pakistan Journal of Nutrition, 5, 14-18. doi:10.3923/pjn.2006.14.18

[24] Odedire, J.A. and Babayemi, O.J. (2008) Comparative studies on the yield andchemical composition of panicum maximum and andropogongayanus as influenced by Tephrosia candida and Leucaena leucocephala. Livestock Research and Rural Development, 20, 1-8. 